\title{
The Relieve Method and Its Related Issues of Executive Aspects about Trademark Infringement in China
}

\author{
Xuemei An \\ Center for studies of IPR in Zhongnan University of Economics \& Law \\ Wuhan 430074, China
}

Tel: 86-20-8560-9980Ｅ-mail: anxuemei@gmail.com

The Scientific Research Fund of Ministry of Education supported the work, Serial number is 05JJD820017

\begin{abstract}
Trademark is a kind of "privacy right", the major method to protect it is to use civil law in foreign country. But in china, there are two tracks to protect trademark right, which are called the Judicial and Administrative actions with Chinese characteristics. Moreover, administrative protection has become the major method to protect intellectual properties.
\end{abstract}

Keywords: The Relive Method, Trademark, Infringement, Administration

Trademark is a kind of "privacy right". The major method to protect it is to use civil law in foreign countries, and only take executive relieve under some special situations, like customs protection. However Chinese trademark protection is different from that of in other countries, by reasons of administrator consider that trademark is relating to product quality control and consumer's benefit, and while infringement has happened, it is also violating the social welfares. Therefore there are two tracks to protect trademark right, which are called the Judicial and Administrative actions with Chinese characteristics. The former protects the intellectual property by judicial approach, whose intellectual right is through the People's court to prosecute infringer, and investigate the legal responsibility for infringement. The latter is to take action by state administrative departments to manage and punish the infringement. In China, administrative protection has advantages of efficiency, period and cost than judicial protection, which became the major approach to protect intellectual properties. In recent years, this system with Chinese characteristics has helped to against counterfeiting registered trademark, stop trademark infringement and effective protection of the exclusive right to use of registered trademarks, which played a very important role by significant effectiveness. In China 80 to 90 percent of the trademark cases were investigated by industrial and commercial administrative organs at present.

According to Chinese legal provisions, when trademark's specific right has been infringing, the registered and interested relaters can choose to complaint to trademark administrative management office. In China the departments who have right of trademark enforcing the law are: State Administration for Industry and Commerce Trademark Office, Trademark if the Vetting Committee in State Administration for Industry and Commerce Trademark Office, the provincial Industrial and Commercial Administration departments and county level of Industrial and Commercial Administration departments. The State Administration for Industry and Commerce Bureau is mainly responsible for trademark application and registration, prosecuting cases of trademark infringement if necessary, responsible for affirming the well-known trademarks and guidance lower level trademark administration authorities. The State Administration for Industry and Commerce sets up a professional committee, whose mainly responsibility is to deal with the trademark disputes, but has no right to deal trademark infringement. Generally the provincial Industry and Commerce management authority is the trademark office, being responsible for investigating and dealing with the trademark infringement cases and well-known trademarks of transfer, confirmation and protection work. The county level and above trademark Trade and Industry Authority management department (as trademark office) is mainly responsible for trademark infringement cases, handling of complaints and mediation. Naturally, local Industry and Commerce Administration department can also take the initiative to investigate and deal the violations in accordance with terms of reference of infringement to administrative penalties people. Besides there are other offices inside those departments, they are mainly responsible for monitoring the marketing trade actions, suppression of monopolies and unfair competition.

For trademark oblige, the most common relief approach means the administrative relief after oblige applied to the local administration departments. 


\section{Procedures of administrative relief by trademark infringement}

If trademark oblige selects to relieve by administrative protection, it will be suitable to administrative protection procedure. In China, the county level Industry and Commerce administrative organs accepted mainly execute the trademark infringement cases.

\subsection{The choice of case handled department}

When the right of trademark has violations, oblige or agent need to select an appropriate department to handle the case, the Trademark office and Economy inspect office inside the Trade and Industry Bureau are dealing with different infringement cases. Generally, as the counterfeiting of oblige registered trademark or the application as inclusive by oblige trademark, or the malicious registration of other oblige registered trademark, complaints has to select the trademark office in Industry and Commerce department (such as Trademark office). If oblige is not using their trademark directly as the trademark, but used other way to easily caused confusions, like use the similar trademark name, packaging, decorating and etc as policy trademark, which caused confusion of other registered trademark product, affect consumers misunderstandings or unauthorized use of similar trademark as enterprise registered trademark product, may caused misunderstanding, all above can sue at the Economy inspect office inside Industry and Commerce Bureau. Sometimes, the infringement actions are involving directly trademark infringement and also the customers misunderstanding situation, agent need to base on specific situation to choose a stronger enforcement department to act admissibility agencies.

\subsection{Cases accept procedures and related issues}

According to the Chinese legal provisions to require the administration relief, firstly agent need to prepare complaint files which include complaint document, identity documents and evidence documents if complainant, statement of both parties basic situation in written, the complaints of goods storage location. The tort facts and reasons for request of complainant matters, (like requiring for administrative penalties of infringement), corresponding related evidence like proof of trademark right, evidence of infringement actions or identification of authority or other identification proof documents (such as the identification of trademark already been a well-known trademark) and etc.

After authorities received complaint documents, it will first to review the case than accord the provision to place a case on file for investigation and prosecution to determine the applicable procedures. Under the normal situation, administration department will execute the procedures of taken the main file, investigate and collect evidence, listen parties statements, make administrative punishment, delivery the punishment decision document and etc. If a party against the punishment by authority's decision, it may raise the reconsider to a higher-level authority within 15 days of administrative made the punishment decision date, can also raise an administrative proceeding to the court in the statutory time limitation, or skip the reconsideration and directly raise the administrative proceedings.

The executive can take the administrative measures are ordered to stop the infringement violations, confiscation, destruction infringement goods and product used to produce infringement goods, tools to counterfeit registered trademarks, in order to take punishment and etc. Industry and Commerce department can also arbitrate both parties based on requirement of parties on the amount of compensation for trademark infringement. But this kind of arbitrate do not have administration effect. The party who refused to accept mediation can prosecute at the court.

Based on above matters and compare to civil relief under trademark infringement, in the administration relief process the infringement must accept the punishment which given by nation order, may afford greater economic responsibility.

\section{Related issues need to take attention}

During the practical, trademark violations are often having difficulty to investigate completely, especially in the vast territory of China; some search fee of infringement actions is extremely high, that agents should handle cases flexible.

\subsection{Choice of relief ways}

When the violations are hidden and in a state of flow, agent better choose as combine the administrative penalties, administrative proceeding and civil compensation, it may restrain the infringement actions effetely. Such as oblige or agent often complaints to Industry and Commerce department at first, than let the administration office investigates and treat the infringement actions. If violations against, oblige can always ready to prepare to cooperate with administration office to participate in administrative proceedings, furthered identify the illegal identify infringing acts. In addition oblige can also obtain the relief first than request civil compensation. Therefore the infringement act already been confirmed before litigation procedure, related evidence also collected, so the civil compensation request can achieve easier.

\subsection{Problems need to pay attention}

As the proceedings are major reviewing the legality to make the administration decision, so strategy of combine the administrative and civil contains a certain legal risk. Mainly act as for Industrial and Commercial administrative organs 
of law enforcement of challenges legality procedures. Because of Chinese law enforcement has large difference in quality and law enforcement procedures are not standardized, it may cause risk of administrative proceedings. And lose a lawsuit by illegal procedures will cause negative effect of oblige trademark protection works. Therefore in practice, oblige and agent need to actively cooperate with the Industrial and Commercial administrative department of law enforcement, in order to secure enforcement procedures flawless, for better foundation of administrative proceedings in future.

\section{Conclusion}

By the reason of "Two tracks" protection model's characteristic, it supports an advantage condition to protect trademark in China. Oblige can search for justice relief like abroad countries. On the other hand, it can also receive the administrative department's proactive care. In China, the administrative protection of trademark right play an important role, this contains timely and quick of characteristics of decision. Generally, under the clear tort facts and sufficient evidence, trademark oblige always select the efficient administrative protection. Especially in some situation that judicial protection is powerless occasions, the protection showed a unique advantage. For example according the law provision, when the trademark right's general permits who was found been use of trademark infringement, as the main qualification do not match that can not filed against infringement of trademark right, which only by oblige as a fitness of promoter proceedings, it difficult to effectively curb the infringement. At the point, if the licensee turned to executive authorities can seek to report to administrative protection, in order to stop infringing purposes.

As we well known, every coin has its reverse; the law is enacted which has no perfect legal system over the world. Chinese trademark infringement relief still has some deficiencies; it needs to improve the legislation and judicial practice in the future. From the legislative point of view, Chinese civil legal norms further improved, the well-known trademark need to complete rules, to minimize the vague definition of the scope of trademark right, to confirm trademark obligor's legitimate interest should be protected. By the secretary regulation system, the administrative protection based documents still contain some instability to protect trademark rights, and the right to information relevant stakeholders. In addition, the administration of justice backlog of cases, and investigation delay are the reason of caused many infringement cases were holding for a long period. Furthermore, administrative and judicial protection's combination system has impacts of administer problems and problem of convergence of two protection methods.

Overall, the Chinese government is doing a great improvement of complete trademark legal system, against infringement actions and safeguarding the obligor's benefits. In a short 20 years period, Chinese trademark law system has done the developed country's 100 years history already, the judge's quality and administration justice has improved continuously, basically it formed a better complete trademark protection system, also support an advantage legal environment for Chinese enterprise's foreign trade business and oversea enterprise's intellectual property protection. Also has laid a solid foundation of national economic development in the future.

\section{References}

Gilson. L.B. (2000). On Trademarks Protection \& its Practice. In Mathew Bender \& Company, Torts. Beijing: Law press. pp. 146-147.

High People's Court of Beijing, E.B. (2008). How to protect your trademark in court. In the third Civil Court of High People's Court of Beijing, The practice of intellectual property suit ( $3^{\text {rd }}$ ed.). Beijing: Intellectual Property law Press. pp. 248-251.

Hu, Kaizhong. E.B. (2004). Comparative research on intellectual property law ( $3^{\text {rd }}$ ed.). Beijing: The Chinese People's Public Security University Press, (chapter 6).

Mark A \& Scott. (2005). Changing Meaning of Trademark. Stanford Public Law and Legal Theory Working Paper Series. Research Paper No. 107, March 2005.

Wu, Handong. E.B. (2005). Some basic questions about intellectual property rights $\left(4^{\text {th }}\right.$ ed.). Beijing: The Chinese People's University Press, (Chapter 5).

$\mathrm{Xu}$, Jiali. E.B. (2006). The practice of intellectual property attorneys in china (3 ${ }^{\text {rd }}$ ed.). Beijing: The Court Press, (Chapter 3). 